\title{
Natural Occurrence of the Entomopathogenic Fungus Nomuraea rileyi in the Soybean Green Semilooper, Chry sodeixis acuta, in India
}

\author{
Ved Prakash Gupta, Agricultural Research Station, Ummedganj, \\ Kaithoon Road, Post Box 7, G.P.O. Nayapura, Kota, Rajasthan, India \\ Corresponding author: Ved Prakash Gupta. vpgkth@hotmail.com
}

Gupta, V. P. 2003. Natural occurrence of the entomopathogenic fungus Nomuraea rileyi in the soybean green semilooper, Chrysodeixis acuta, in India. Online. Plant Health Progress doi: 10.1094/PHP-2003-0113-01-HN.

Nomuraea rileyi (Farlow) Samson is an entomopathogenic fungus that infects lepidopteran larvae $(1,2,4,6,7)$. The fungus was observed in populations of the soybean green semilooper, Chrysodeixis acuta, in the humid Southeastern Plain Zone of Rajasthan, India, in 2001. Regular surveys of soybean fields for lepidopteran pests and their natural enemies were conducted in a linear manner around villages in the district of Baran $\left(25^{\circ} 5^{\prime} \mathrm{N}, 75^{\circ} 31^{\prime} \mathrm{E}\right)$ on both sides of the road. During the first survey, five sampling locations were randomly fixed with a mean inter-location distance of $11 \mathrm{~km}$ (ranging from 7 to $15 \mathrm{~km}$ ). At each location, two soybean fields were selected and five samples per field were taken. Observations for larval populations were confined to an area of 0.1 to 0.2 ha. Larval densities were sampled by spreading one meter of white muslin cloth near the bases of the plants and gently tapping the leaves to dislodge the larvae. The numbers of larvae that fell onto the cloth were counted and recorded. Surveys yielded a larval density of 4.75 larvae per row meter on 7J uly, 6.0 larvae per row meter on 23 J uly, 1.1 larvae per row meter on 7 August, 0.2 larva per row meter on 27 August, and 0.0 larva per row meter on 6 September, 2001. The economic threshold level for the looper is 3.0 larvae per row meter at flower initiation (5). This threshold was exceeded by the population densities sampled on 7 and 23 July.

The populations of C. acuta had decreased by the time follow-up surveys in all of the fields were conducted. On 6 September, 2001, in one of the two fields near the village Goverdhanpura $\left(24^{\circ} 40^{\prime} \mathrm{N}, 75^{\circ} 42^{\prime} \mathrm{E}\right)$, all of the C. acuta larvae found were dead on soybean leaves. The larvae were completely covered with the green spore mass of N. rileyi (Fig. 1). The posteriors of the dead larvae were attached to the leaves, with the anterior portions of the bodies hanging in the air (Fig. 2). The infected cadavers were first observed in the field in which the soybean plants were at the R4 growth stage. The average number of dead larvae was 6 per meter of row. It is pertinent to note that deviation in estimates of the densities of live larvae and estimates of the densities of larvae killed by N. rileyi can be partially explained by the method of sampling. The initial gentle tapping of leaves caused the larvae to fall onto the muslin cloth at the bases of the plants. Larvae killed by N. rileyi were attached to the surfaces of leaves and had to be removed with a camel hair brush. This was observed at only one of five locations surveyed. 


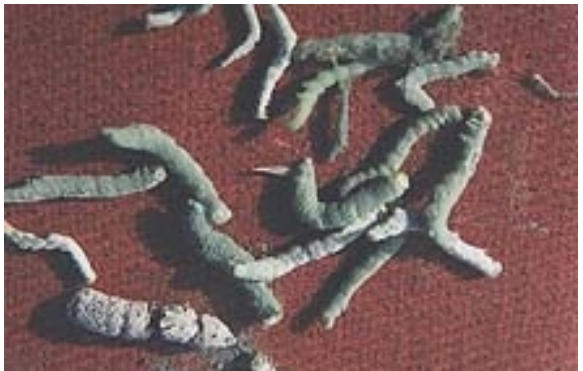

Fig. 1: Infected cadavers of C. acuta covered with green spore mass of $\mathrm{N}$. rileyi.

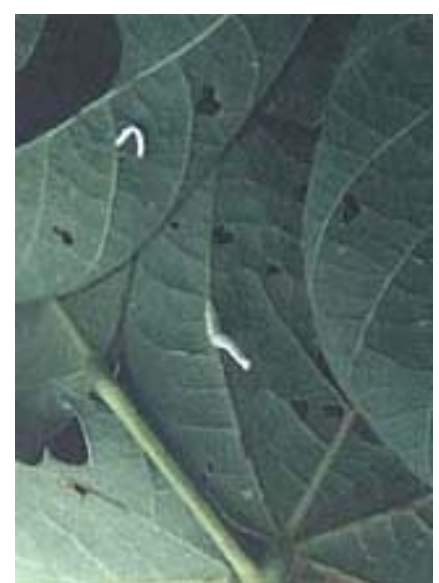

Fig. 2: Dead larvae of C. acuta attached on the surface of soybean leaves.

During the days of sampling (from $2 \mathrm{~J}$ uly through 9 September, 2001), the mean maximum and minimum temperatures and mean maximum (at $0700 \mathrm{hrs}$ IST) and minimum (at $1400 \mathrm{hrs}$ IST) relative humidities ranged from $29.9^{\circ} \mathrm{C}$ to $34.3^{\circ} \mathrm{C}, 24.2^{\circ} \mathrm{C}$ to $25.7^{\circ} \mathrm{C}$, and 82 to 93 percent, and 53 to 78 percent, respectively. The average sunshine hours per day ranged from 2.4 to 9.5, indicating that most of the days were cloudy. The total number of rainy days and rainfall amount were 23 and $804.6 \mathrm{~mm}$, respectively. These environmental conditions are highly favorable for the growth and successful natural infection by the fungus $(3,7)$.

The infected C. acuta cadavers were sent for identification to the Diagnostic and Advisory Service, CABI Bioscience, UK, where the fungus was confirmed as N. rileyi. Thus, N. rileyi caused 100 percent mortality of larvae of C. acuta. This is the first report of the natural occurrence of the fungus $\mathrm{N}$. rileyi on $\mathrm{C}$. acuta in the Rajasthan state of India.

\section{Literature Cited}

1. Ambethgar, V., and Loganathan, M. 1998. Incidence of green muscardine fungus, Nomuraea rileyi (Farlow) Samson, on Spodoptera litura (Fab.) in soybean, Glycine max (L.) Merrill, from Tamil Nadu (India). J . Entomol. Res. 22:195-196.

2. da Silva, M. T. B. 1993. Control of the soyabean caterpillar (Anticarsia gemmatalis (Hübner, 1818) (Lepidoptera: Noctuidae). IV. Natural biological control. Ciencia Rural 23: 127-132.

3. de Faria, M. R., Tigano-Milani, M. S., and Lecuona, R. E. 1993. Natural incidence of Nomuraea rileyi Farlow in a population of Anticarsia gemmatalis Hübner in Federal District. An. Soc. Entomol. Brasil 22:385-388.

4. Ferron, P. 1978. Biological control of insect pests by entomopathogenic fungi. Ann. Rev. Entomol. 23:409-442.

5. Singh, O. P., Verma, S. N., and Nema, K. K. 1989. Insect Pests of Soybean in India. International Book Distributors, Dehra Dun, India.

6. VimlaDevi, P. S., and Prasad, Y. G. 2001. Nomuraea rileyi: A potential mycoinsecticide. Pages 23-38 in: Biocontrol Potential and its Exploitation in Sustainable Agriculture, Volume 2, Insect Pests. R. K. Upadyay, K. G. Mukherji, and B. P. Chamola, eds. Kluwer Academic/ Plenum Publisher, New York.

7. VimalaDevi, P. S., Prasad, Y. G., Rajeshwari, B., and Vijay Bhaskar, L. 1996. Epizootics of the entomofungal pathogen, Nomuraea rileyi, on lepidopterous pests of oilseed. J. Oilseeds Res. 13:44-148. 